\title{
「人にはどれだけの科学技術情報が必要か」に応えて
}

\section{In Response to "Science Information and Basic Human Right”}

\author{
石塚英弘 \\ Hidehiro ISHIZUKA \\ 月例㤅話会担当常務理事
}

「人にはどれだけの科学技術情報が必要か」は、 2007 年 3 月に開催された月例懇話会の講師 : 横浜国立大学理事・中部大学特任教授の長島昭 先生から聴衆と本学会会員に発せられた問い 掛けの言葉である。

この講演は実に示唆に富んでいた。月例懇話 会担当者で聴衆でもあった私は、その問い掛け を情報知識学に対する重要な課題と受け取っ た。本学会会員のために講演内容を長島先生に 書いていただきたいと思ったが、多忙の先生に は執筆に割く時間があろうはずも無い。そこで、 巻頭言を書くこの機会に、私が講演内容の概略 をご紹介するとともに私なりの考えも述べる ことにした。

長島先生の元々のご専門は物質の性質を測 定して研究する分野 (熱物性) であったが、測 定で得られたデータや科学技術情報を扱う研 究に展開し、現在は、データと情報に関する国 際委員会 CODATAの日本代表である。その一 方で、国立大学理事として大学経営にも参画し た結果、今や科学技術情報から経営情報に至る 広い視野に立って情報の重要性を認識されて いる。

まずは講演内容を紹介する。現在の社会では、 貧富の差は拡大寸る一方であり、途上国と先進 国の差も拡大しているが、その一因は情報の差 にある。私たちが人間らしく生きていくには、 最小限どれだけの科学技術情報が必要なのか。 そのために私たちは何をすればよいのか。これ が長島先生の問い掛け、問題提起である。Web 上などに大量の情報が在るから、それを調べれ ばよいと考える方もいると思うが、本当にそう
なのか。大学理事会の会議でも大量の資料が配 布される。大量に情報を提供すれば、それで良 いと思っているのではないか。それらは全て必 要なものなのか。必要な情報が提供されている のか。長島先生は、人間が人間らしく生きてい くために必要な情報の例を、薬の情報、医学的 情報、法律の情報、税金の情報、等々次々に挙 げた。たとえば、全ての薬の情報ではなく、患 者が本当に必要とする情報を得られるように なっているのだろうか、また、政府から提供さ れるべき情報がそれを必要としている人に提 供されているかという訳である。

この問い掛けは重要かつ困難な課題である と私は思った。たとえば、単に或る薬の情報が 得られればよいのではなく、治療すべき疾患に 関する医学情報も必要であり、断片的な情報で はなく、それを理解するための知識も必要であ る。研究の進展によって情報や知識が変わるこ とは少なくないから、断片的ないし断定的な情 報を覚えていても役に立たす、その根拠となる 情報や知識の枠組みを知っていることの方が 重要である。これは教育の問題にも関連する。 また、薬害エイズ事件の時には伝えられるべき 情報が隠されていたことを思い出す。さらに、 この講演の約 3 ケ月後、誰のものか不明な年金 保険料納付情報 5 千万件の存在が暴露された。 正に示唆に富んだ講演である。長島先生の問い 掛けを会員各位が受け止めてくださることを 期待する次第である。 